\title{
Geloofsverryking te midde van moreel-etiese verwarring in die lig van die kenmotief in 2 Petrus 1:5-7
}

Douw. G. Breed \& G.J.C. Jordaan

Skool vir Bybelwetenskappe \& Bybeltale

Potchefstroomse Universiteit vir $\mathrm{CHO}$

POTCHEFSTROOM

E-pos: ontgjcj@puknet.puk.ac.za

E-pos: dbreed@spyda.co.za

\begin{abstract}
Spiritual enrichment of Christians in the midst of moral-ethical confusion in the present South Africa: the significance of the motif of knowing in 2 Peter 1:5-7

In this article, which deals with the significance of the motif of knowing in 2 Peter 1:5-7 for the present South African context, attention is paid to $\pi i \sigma \tau \iota s$ and $\gamma \nu \hat{\omega} \sigma \iota s$ in verses $5-7$. This article attempts to indicate that Peter's encouragement of his readers to enrich their belief has special significance for believers in South Africa. Believers should understand that accepted religious beliefs ( $\pi i \sigma \tau \iota S)$ are only a basic virtue. To this virtue they have to add, together with other virtues, the faculty of comprehension $(\gamma \nu \hat{\omega} \sigma \iota s)$. In South Africa, opposing statements are currently often made about what Scripture teaches concerning moral issues. Believers having this ability of comprehension will be able to judge these statements and arrive at a Biblically-oriented conclusion.
\end{abstract}

\section{Inleiding}

\subsection{Petrus 1:5-7 en die huidige Suid-Afrikaanse konteks}

Op moreel-etiese terrein word tans in Suid-Afrika heel dikwels botsende standpunte ingeneem. Propageerders van hierdie botsende standpunte beroep hulle soms op die Skrif. As voorbeeld kan die volgende genoem word: De Klerk (1998:98) bepleit byvoorbeeld 'n meer toegeeflike houding by Christene teenoor seksuele gemeenskap voor die huwelik. 
Hy sê:

Vandag word dit algemene praktyk dat seks voor en sonder die huwelik in liefdesverhoudings beoefen word. In plaas daarvan om dit gelate te aanvaar of dié mense te bearbei dat hulle met hulle sonde moet breek, moet die kerk begin om krities na sy eie opvattings te kyk.

Om sy standpunt te motiveer beroep hy hom op die feit dat daar teoloë is wat "Bybeltekste wat dit dan sou verbied, anders uitlê". Van Rooy (1998: 7) wys daarop dat De Klerk nie aangaande die voorhuwelikse seks van sonde praat "waarvoor daar om Christus ontwil vergifnis gevra moet word nie...", maar dat De Klerk se standpunt daarop neerkom dat voorhuwelikse seks hoegenaamd nie sonde is nie. Teenoor De Klerk stel De Bruyn (1993:169) "... dat volgens die Ou en Nuwe Testament geslagsgemeenskap voor die huwelik teen die wil van God is en as sonde veroordeel moet word. Dit is onversoenbaar met die lewe van die ware Christen". De Bruyn beroep hom vir sy standpunt op Skrifgedeeltes soos Deuteronomium 22:13-19, Hooglied 8:8-10, Matteus 15:19 en 1 Korintiërs 7:2.

'n Verdere voorbeeld van botsende standpunte op moreel-etiese terrein is die volgende: Landman (1999:6) stel byvoorbeeld die volgende:

Die Bybel is aan vroue se kant wat vir poligamie veg. Het die aartsvaders dan nie baie vroue gehad nie? Wat van Dawid en Salomo? En wat sou van Rut geword het as Boas net een vrou gehad het? En het Rut hom nie doelbewus gesoek nie?

Breed (1999:6) sê daarteenoor: "Dwarsdeur die Bybel word dit uitgespel dat God se wil vir die huwelik ... een man een vrou [is], en telkens word dit onder ons aandag gebring dat afwyking daarvan moeilikheid beteken". De Bruyn (1993:184) erken dat poligamie in Israel aan die orde van die dag was, maar sê dat sowel Christus as Paulus monogamie "bo alle twyfel" as normatief gestel het.

Jackson (1999:11) wys daarop dat daar in kerklike kringe in Suid-Afrika groot verskille bestaan oor die vraag wat die Bybel leer aangaande die uitleef van homoseksualiteit in 'n vaste verhouding. Ook Du Toit (1999:6) sê dat kerke in Suid-Afrika nie hieroor duidelikheid het nie. Die groot saak waaroor daar by kerke onduidelikheid bestaan, het volgens hom betrekking op mense wat "toegewyde, sensitiewe Christene" is en wat "moes ontdek dat hulle 'natuur' net eenvoudig anders is".

Uit die voorgaande voorbeelde is dit duidelik dat Christene in Suid-Afrika gekonfronteer word met botsende standpunte waarin die propageerders 
hulle telkens op die Skrif beroep. Vir Christene is hierdie botsende standpunte uiters verwarrend. Dit word vir die gelowige moeilik om te bepaal hoe hy hom "moet beywer om vlekkeloos en onberispelik voor God en in vrede met Hom te lewe" (2 Petrus 3:14). 2 Petrus 1:5-7 mag moontlik leiding gee aan gelowiges wat op die moreel-etiese terrein deur verskillende standpunte verwar word. Petrus se lesers is immers ook verwar deur valse leraars wat 'n lewe volgens eie begeertes voorgestaan het en wat hulle op die Geskrifte en op Paulus se briewe beroep het (Breed, 1994:332-336). Vir hierdie mense sê Petrus in 1:5-7 dat hulle hulle geloof moet verryk. Hulle moet sekere deugde en spesifiek kennis $(\gamma \nu \hat{\omega} \sigma \iota s)$ by hulle geloof voeg.

\subsection{Die kenmotief en 2 Petrus 1:5-7}

In 'n artikel oor 1 Petrus 1:3-4 is aangedui (Breed, 2000) dat daar in 2 Petrus 1:3-11 'n herhaalde betekenisvolle element is, 'n semantiese eenheid wat ongewysig of met ligte variasies voorkom en wat vir die doeleindes van dié artikel die kenmotief genoem word. Hierdie kenmotief word deur Petrus na vore gebring waar die besit van inligting ter sprake is (vgl. Breed, 2000). Wanneer die skrywer dus woorde soos $\gamma \nu \hat{\omega} \sigma \iota s$ en $\epsilon \in i ́ \gamma \nu \omega \sigma \iota s$ gebruik, bring hy daarmee die kenmotief na vore. Daar is ook aangedui dat in die identifisering van die kenmotief rekening gehou moet word met woorde wat, binne hulle konteks genome, in betekenisvelde gebruik word wat met die begrip kennis verband hou1. Dit sluit onder

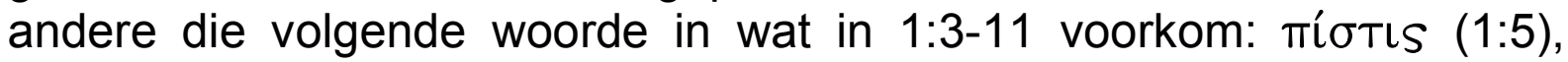

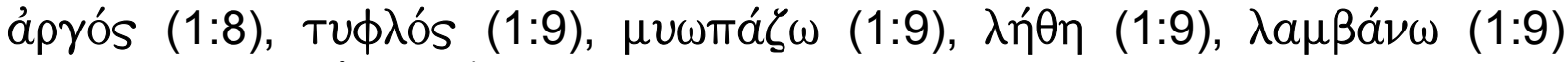

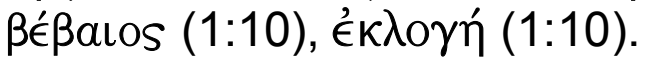

\subsection{Die gedagtekonteks van 2 Petrus 1:5-7}

In 'n vorige artikel oor 2 Petrus 1:3-4 (vgl. Breed, 2000) is aangedui dat 2 Petrus 1:3-11 uit drie gedagte-eenhede bestaan:

$\begin{array}{ll}1: 3-4 & \text { 'n Historiese of teologiese gedeelte } \\ 1: 5-10 & \text { 'n Etiese aanmoedigingsgedeelte } \\ 1: 11 & \text { 'n Eskatologiese gedeelte }\end{array}$

Breed $(1994: 74,77)$ toon aan dat die etiese aanmoedigingsgedeelte uit twee kleiner gedagte-eenhede bestaan. In die eerste gedagte-eenheid (1:5-7) handel Petrus oor die deugde wat die gelowiges by hulle geloof moet voeg en in die tweede gedagte-eenheid motiveer hy sy lesers om eties korrek te lewe. Vir die doeleindes van hierdie artikel word na die

1 Vergelyk Breed (2000) waar aangedui word watter woorde met die besit van inligting verband hou. 
eerste kleiner gedagte-eenheid verwys as gedagte-eenheid $A$ en na die tweede as gedagte-eenheid $B$. In hierdie artikel word die kenmotief in gedagte-eenheid $A$ bestudeer en word gewys op die betekenis daarvan vir die huidige Suid-Afrikaanse konteks.

Vanweë die feit dat 2 Petrus 1:3-11 'n hegte eenheid vorm, word in 'n opvolgartikel aandag gegee aan die kenmotief in gedagte-eenheid $B$ en in die eskatologiese gedeelte. Ook word die betekenis daarvan vir die huidige Suid-Afrikaanse konteks aangetoon.

\section{Die kenmotief in gedagte-eenheid A van die aanmoedigingsgedeelte (1:5-7) en die betekenis daarvan vir Christene in Suid-Afrika}

Die woorde in gedagte-eenheid A wat die kenmotief na vore bring, word eerstens ondersoek en tweedens word die plek wat die kenmotief in gedagte-eenheid A inneem, nagevors.

\subsection{Woorde in gedagte-eenheid A wat die kenmotief dra}

In gedagte-eenheid $A$ word twee woorde gebruik waarin die kenmotief

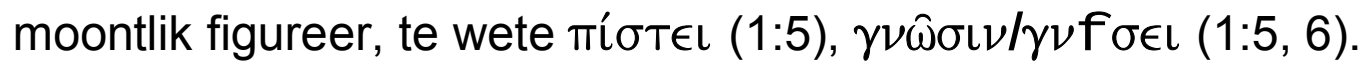

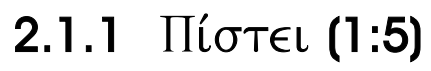

Die feit dat Petrus reeds in 1:1 duidelik gemaak het dat die lesers (soos

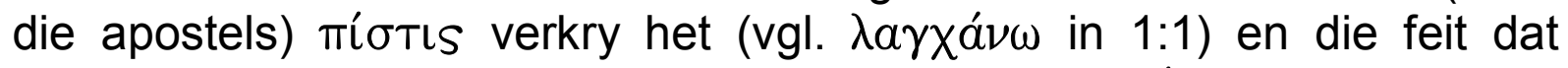
Petrus in 1:5-7 veronderstel dat die lesers reeds die míotıs het, laat blyk dat hy $\pi i ́ \sigma \tau \epsilon \iota$ in 1:5 in dieselfde semantiese veld aanwend as waarin dit in 1:1 aangewend is. In 'n vorige artikel (vgl. Breed, 2000) is aangetoon dat Petrus míotıs in 1:1 asook in 1:3 (deur die gebruik van die woord " $\pi \alpha ́ \nu \tau \alpha ")$ aanwend in die semantiese veld 'n perspektief hê, glo, vertrou (31). Semantiese veld 31 (Louw \& Nida, 1988a:334) hou met die kenmotief verband. Dit blyk dus dat Petrus die kenmotief deur die

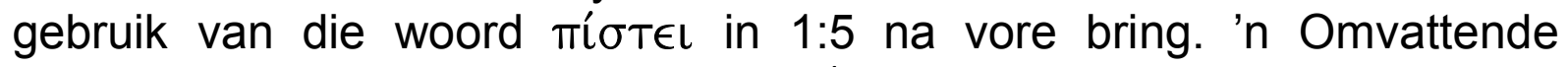
komponente-analise van die woord mí $\sigma \tau$ ts (vgl. Breed, 2000) het aangetoon dat die woord in 1:5 na 'n stel geloofswaarhede verwys waaroor tot 'n besluit gekom is en wat reeds aanvaar is. Daar is aangedui dat die

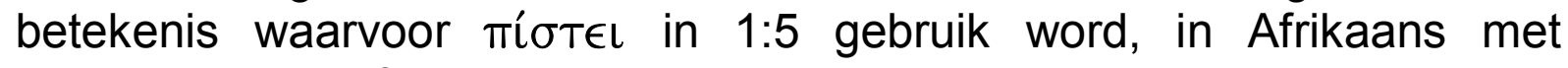
aanvaarde geloofswaarhede weergegee kan word.

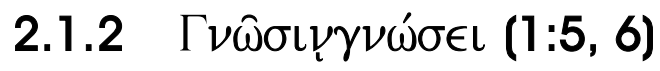

Die woord $\gamma \nu \omega \hat{\sigma}$ เs word volgens Louw en Nida (1988b:52) in twee semantiese velde aangewend, te wete die veld ken (28) en die veld 
verstaan (32). Semantiese veld 28 het betrekking op die besit van inligting, terwyl veld 32 verwys na die proses waardeur die inligting gebruik word om tot 'n korrekte begrip en gevolgtrekking te kom (vgl. Louw \& Nida, 1988a:380). Die konteks waarin Petrus $\gamma \nu \omega \hat{\omega} \sigma \mathrm{s}$ in 1:5 en 6 gebruik, dui daarop dat $\gamma \nu \omega \hat{\sigma} \iota s$ in hierdie geval na 'n betekenis in semantiese veld 32 verwys. In die brief laat Petrus immers nie die klem val op die vermeerdering van kennis nie. In 1:12 maak hy dit duidelik dat die lesers reeds kennis dra van die leer van die apostels. Ook in hoofstukke 2 en 3 handel Petrus nie oor die lesers se gebrek aan inligting nie, maar benadruk hy die inligting wat hulle het en hoe hulle dit moet verwerk. Hulle weet byvoorbeeld dat daar valse profete was (2:1), wat gebeur het met die engele (2:4), die ou wêreld, Noag (2:5), Sodom en Gomorra (2:7). Hulle het ook volgens 3:2 inligting wat hulle van die profete en die apostels ontvang het. Wanneer Petrus dus in 1:5 van die lesers verwag om $\gamma v \omega \hat{\sigma}$ เs by hulle geloof te voeg, verwys hy na die korrekte begrip en konklusie waartoe hulle moet kom.

Petrus gebruik daarom in 1:5 die woord $\gamma \nu \omega \hat{\omega} \sigma \mathrm{s}$ in semantiese veld 32. Hierdie semantiese veld 32 hou met die kenmotief verband en Petrus

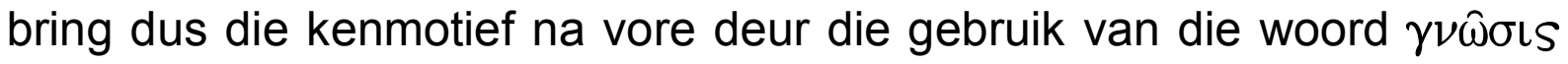
in $1: 5$.

Binne semantiese veld 32 verstrek Louw en Nida (1988a:380-388) een en sestig betekenisse wat in die volgende vyf subdomeine verdeel word. $\Gamma \nu \omega \hat{\sigma} \mathrm{ls}$ word slegs aangewend in die subdomein tot begrip kom (B) en wel vir die betekenis om tot begrip te kom as gevolg van die vermoë om te ervaar en te leer (Louw \& Nida, 1988a:382). Wanneer semantiese veld 32 met die omliggende semantiese velde gekontrasteer word, blyk dit dat $\gamma \nu \omega \hat{\omega} \mathrm{ls}$ in 1:5 en 1:6 verband hou met die verwerkingsproses van inligting waardeur tot die korrekte begrip of evaluering gekom kan word. Hoewel subdomein $B$, soos ander subdomeine in die semantiese veld verstaan, die vermoë om te verstaan, impliseer, val die klem in subdomein B op die proses waardeur iemand tot die verstaan van iets kom. Dit blyk dat $\gamma \nu \hat{\omega} \sigma \iota \nu / \gamma \nu \omega \dot{\sigma} \sigma \in \mathrm{\iota}$ in 1:5 en 1:6 na die proses verwys waardeur iemand tot die verstaan en begrip van iets kom.

Die kontrastering van die betekenis waarvoor $\gamma \nu \hat{\omega} \sigma \iota \nu / \gamma \nu \omega ́ \sigma \in \mathrm{l}$ in 1:5 en 1:6 gebruik word (32.16), met die ander betekenisse (32.11-32.15 en $32.17-32.18$ ) in dieselfde subdomein, toon dat die woord $\gamma \nu \omega \hat{\sigma} / \mathrm{s}$ in $1: 5$ en 6 verband hou met die proses om tot begrip te kom, en dat hierdie begrip die resultaat is van die vermoë om te leer en te ervaar. Dié woord verwys in 2 Petrus na die evaluering van inligting waaroor die lesers beskik in ooreenstemming met dit wat Petrus in sy brief aan die lesers nalaat. Die betekenis waarvoor $\gamma \nu \hat{\omega} \sigma \iota s$ in 1:5 en 1:6 gebruik word, sou in Afrikaans met begripsvermoë be-teken kon word. 


\subsection{Die kenmotief in gedagte-eenheid A (1:5-7), soos gedra deur die woorde $\pi i ́ \sigma T \in l$ en $\gamma \nu \hat{\omega} \sigma \iota s$}

Ten einde vas te stel tot watter mate die woorde $\pi i ́ \sigma \tau \epsilon \iota$ (1:5) en $\gamma \nu \hat{\omega} \sigma \iota s$ $(1: 5,6)$ in gedagte-eenheid A die kenmotief dra, word die voorkoms van deugdelyste in die Nuwe-Testamentiese tyd eerstens ondersoek. In die

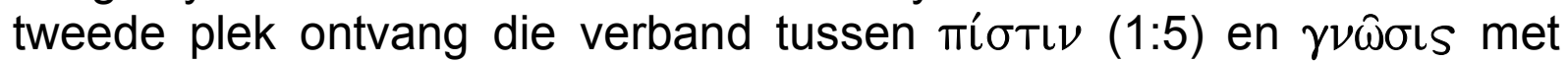
gedagte-eenheid $\mathrm{A}$ aandag.

\subsubsection{Die deugdelys in die Nuwe-Testamentiese tyd}

Navorsing wat onderneem is deur onder andere Easton (1932:1-12) en Wibbing (1959:80-81; 84-85; 104) bevestig dat Nuwe-Testamentiese skrywers dikwels gebruik gemaak het van deugdelyste. Deugdelyste kom onder andere voor in Romeine 5:3-5, 2 Korintiërs 6:6, 2 Korintiërs 8:7, Galasiërs 5:22, Efesiërs 4:2-3, Filippense 4:8, 1 Timoteus 4:12, 6:11, 2 Timoteus 3:10, 1 Petrus 3:8, Titus 2:2 en Openbaring 2:19.

Fischel (1973:119) toon aan dat Stoïsynse en Hellenisties-etiese skrywers gebruik gemaak het van deugdelyste in die soritesvorm. In hierdie deugdelyste was deugde op so 'n wyse aan mekaar verbind dat die een deug uit die ander ontwikkel het sodat daar stapsgewys tot 'n klimaks opgebou is. Deur hierdie deugdelyste het die skrywers 'n memoriseerbare opsomming gegee van wat hulle as 'n goeie lewe beskou het. Dit is duidelik dat Petrus by hierdie gebruik van Stoïsynse en Hellenistiese skrywers in vers 5-7 aansluit. Fornberg (1977:100) waarsku egter tereg: "This does not mean, however, that the list gives voice to Greek religiosity" (vgl. ook Green, 1961:66). Die ooreenkoms wat die deugdelys in 2 Petrus in hierdie verband toon met 2 Korintiërs 8:7 en 1 Korintiërs 13:13, asook met Ignatius (1977:188) se woorde aan die Efesiërs (Efesiërs 14.1) oortuig dat die deugdelys in 2 Petrus binne die kader van die Nuwe Testament val.

Dupont (1949:393-398) toon aan dat daar getuienis is dat dit 'n gevestigde gebruik by Christelike skrywers was om deugdelyste met

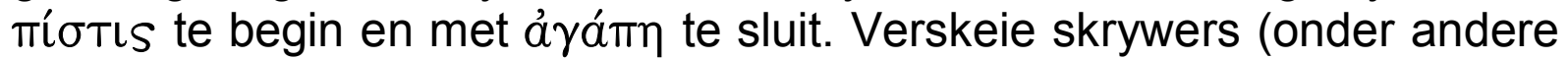
Bauckham, 1983:185, Bolkestein, 1977:255 en Grundmann, 1974:72) wys daarop dat daar in 2 Petrus 1:5-7 nie 'n logiese verband is tussen die deugde soos dit in die lys op mekaar volg nie. Die skrywer wil dus nie, soos die Stoïsyne (Wibbing, 1959:19), in die deugdelys 'n trapleer aantoon waarvolgens die mens van die laer deugde na die hoër deugde vorder nie (vgl. punt 2.2.1). Die feit dat die deugde nie logies met mekaar verband hou nie, wys daarop dat die skrywer met die sewe deugde wat na $\pi i ́ \sigma \tau \iota \nu$ volg, verskillende aspekte van 'n lewe volgens God se wil 
weergee. Hierdie deugde dien as opsomming van 'n lewe volgens God se wil.

Die feit dat Petrus reeds in verse 1-4 aandag gegee het aan 'n besondere leefwyse, te wete 'n leefwyse volgens God se wil (vgl. Breed, 2000), bevestig dat Petrus met die deugdelys in 1:5-7 aan die lesers verduidelik wat 'n lewe volgens God se wil behels. In 'n lewe volgens God se wil, kom die deugde wat in 1:5-7 genoem word voor.

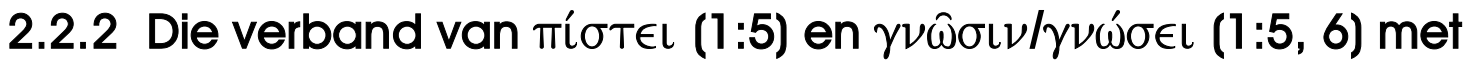 gedagte-eenheid A}

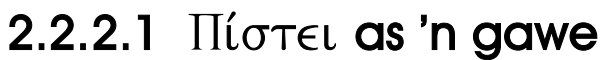

Dit is opmerklik dat daar nie in die deugdelys van die lesers verlang word om die aanvaarde geloofswaarhede as deug by te voeg nie, terwyl die lesers wel aangemoedig word om die ander deugde by te voeg. Dat Petrus veronderstel dat die lesers reeds oor die aanvaarde geloofswaarhede beskik, blyk reeds duidelik uit die aanhef van die brief (1:1), waar hy sy lesers bekendstel as mense wat reeds die aanvaarde geloofswaarhede besit. Hulle het die geloofswaarhede deur goddelike guns en keuse bekom². Waar Petrus weer in die deugdelys (1:5) na die aanvaarde geloofswaarhede van sy lesers verwys, is sy bedoeling steeds dat hulle die geloofswaarhede deur goddelike begenadiging bekom het.

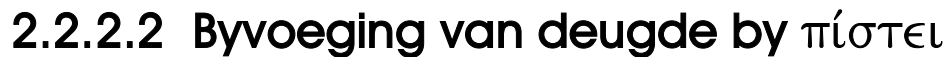

Terwyl dit duidelik is dat die aanvaarde geloofswaarhede 'n deug is waaroor die lesers reeds beskik, blyk dit dat Petrus van sy lesers verwag om nie met die besit van die geloofswaarhede te volstaan nie. Hy maak dit duidelik dat die besit van die geloofswaarhede tot verdere aktiwiteit moet lei. Petrus sê die lesers moet iets addisioneel voorsien ${ }^{3}$ by dit wat reeds bestaan. Hulle moet ander deugde by die aanvaarde geloofswaarhede byvoeg. Geloof is die gronddeug waaroor die lesers beskik (Schlatter, 1964:101-102) waarby hulle ander deugde moet voeg.

Deur die gebruik van die voorsetsel $\epsilon$ $\nu$ saam met die datief $T \hat{n} \pi i ́ \sigma \tau \epsilon l$, dui Petrus aan dat die ander deugde nie bloot by die aanvaarde geloofswaarhede gevoeg moet word nie. Hiebert (1984:45) maak Petrus

2 Vergelyk Louw en Nida (1988b:572) vir die betekenis waarvoor Petrus $\lambda a x \circ \hat{\sigma} \sigma \iota \nu$ in 1:1 gebruik.

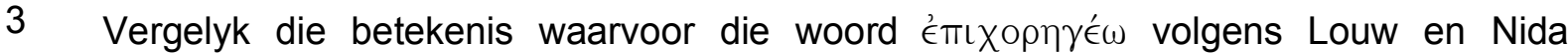
(1988a:603) gebruik word. 
se gebruik van $\tau \hat{n}$ saam met die datief duidelik wanneer hy sê: “... each new trait is introduced as being 'in' ( $\dot{\epsilon} \nu)$ or 'in connection with' the preceding. Each is inherent in the preceding, which in turn is supplemented and perfected by the new". Dit blyk dus dat Petrus die deugde beskou as ' $n$ integrale deel van mekaar en in besonder as deel van die gronddeug, die aanvaarde geloofswaarhede. Dit is nie moontlik dat iemand slegs die geloofswaarhede kan hê sonder dat die ander deugde daarvan deel word nie. Wanneer die geloofswaarhede ontvang is, roep dit as 't ware na die byvoeging van die ander onderskeie deugde.

Uit bostaande word dit duidelik dat Petrus aan sy lesers uitwys dat die besit van die geloofswaarhede wat hulle ontvang het, die gronddeug is. Hierdie gronddeug moet egter daartoe lei dat verskillende ander deugde bygevoeg word.

\subsubsection{3 $\Gamma \nu \hat{\omega} \sigma \iota s$ as een van die deugde in die deugdelys}

In punt 2.2.2.2 is aangetoon dat die skrywer in die deugdelys ' $n$ opsomming gee van deugde en dus nie poog om alle moontlike deugde weer te gee nie. Die vraag is egter waarom hy dit juis belangrik vind dat hierdie sewe deugde by die aanvaarde geloofswaarhede gevoeg moet word, en meer spesifiek, waarom $\gamma \nu \omega \hat{\omega} \sigma \iota s$, waarin die kenmotief na vore kom, bygevoeg moet word.

Saam met Greijdanus (1929:249, 251) kan aanvaar word dat die skrywer, in die saamstel van die deugdelys, rekening gehou het met die omstandighede van die geadresseerdes. Om te bepaal waarom Petrus spesifiek die deug $\gamma \nu \omega \hat{\sigma} \mathrm{s}$ in die deugdelys invoeg, is dit dus nodig om kortliks aandag te gee aan die omstandighede van die lesers.

Uit 2 Petrus 2 en 3 is dit duidelik dat die eerste lesers te doen gehad het met valse leraars. Breed (1994:30-31) toon aan dat hierdie leraars 'n groter toegeeflikheid teenoor 'n heidense leefwyse verkondig het (vgl. die "vryheid" wat volgens 2:19 deur die leraars verkondig is). Christene kon volgens hierdie leraars ook meedoen aan seksuele immoraliteit, dronkenskap en ander uitspattighede (vgl. 2:2, 10a, 13-14, 18). Die ontkenning van die uiteindelike oordeel wat in hoofstuk 3 van die brief aan die orde gestel word, kan ook in hierdie lig verklaar word. Die valse leraars sou met die moontlikheid van 'n toekomstige oordeel moes afreken voordat die boodskap van versoening met 'n heidense leefwyse by die Christene sou posvat. Dit is uit die brief duidelik dat die leraars hulle veral toegespits het op mense wat pas tot geloof gekom het. In 2:18 verwys Petrus daarna dat die valse leraars diegene verlei het wat waarlik die mense wat in dwaling lewe, ontvlug het. In 2:20 noem hy dat mense wat die besmetting van hierdie wêreld ontvlug het, weer verstrik en 
oorwin kan word (vgl. Breed, 1994:27). Die valse leraars het in hulle verkondiging volgens Petrus 'n agressiewe beleid gevolg. Volgens 3:3-4 het hulle met geloofswaarhede gespot. Hulle spot was veral op die Goddelike oordeel gefokus (Breed, 1994:293-294). Volgens 3:16 het hierdie mense ook nie geskroom om die briewe van Paulus te verdraai en dan ter ondersteuning van hulle valse leer aan te bied nie (Breed, 1994:333-334).

In die lig van bogenoemde gegewens is dit duidelik waarom Petrus dit belangrik ag dat die lesers juis begripsvermoë ( $\gamma \nu \hat{\omega} \sigma \iota s)$ by hulle geloof moet voeg. Hulle omstandighede verg dat hulle nie slegs oor geloofs-

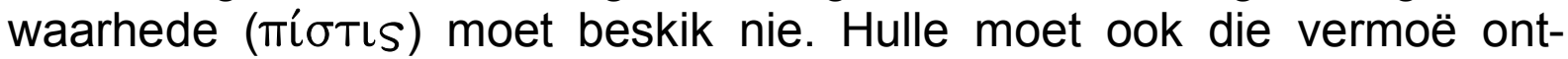
wikkel om met begrip inligting waaroor hulle beskik in ooreenstemming met die leer wat aan hulle verkondig is, te evalueer (vgl. punt 2.1.2 vir die betekenis waarvoor $\gamma \nu \hat{\omega} \sigma \mathrm{s} s$ in 2 Petrus gebruik word). Wanneer die valse leraars aan die lesers verkondig dat hulle oor "vryheid" (2:19) beskik en daarom kan meedoen aan seksuele immoraliteit, dronkenskap en ander uitspattighede (vgl. 2:2, 10a, 13-14, 18) en wanneer die leraars beweer dat die mens nooit voor God rekenskap sal gee oor sy sonde nie, sal hulle, as hulle oor begripsvermoë beskik, die valsheid van die leer herken. Die lesers sal ook, deurdat hulle oor begripsvermoë beskik, besef dat die valse leraars hulle slegs op Paulus se briewe kan beroep omdat hulle Paulus se briewe verdraai. Begripsvermoë sou veral belangrik wees vir dié mense wat pas tot geloof gekom het. Indien hulle oor die vermoë beskik om inligting in ooreenstemming met dit wat Petrus nalaat, te evalueer, sou hulle nie deur die valse leraars tot hulle ou leefwyse verlei word nie.

\subsubsection{Die belangrikheid daarvan om begripsvermoë $(\gamma \nu \hat{\omega} \sigma \iota \nu)$ by geloof ( $\pi i \sigma \tau \epsilon l)$ te voeg}

Uit 2 Petrus is dit duidelik hoe belangrik die skrywer dit ag dat die lesers begripsvermoë ( $\gamma \nu \hat{\omega} \sigma \iota s)$ by hulle geloof voeg. In 3:18 roep hy die lesers

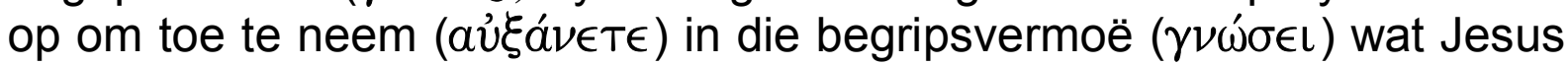
Christus aan hulle gee. 4 Hierdie oproep moet teen die agtergrond van sy waarskuwing in 3:17 verstaan word. Hy waarsku in 3:17 dat die lesers hulle innerlike standvastigheid kan verloor indien hulle toelaat dat hulle deur dwalinge meegesleep word. Die lesers moet toeneem in begripsvermoë sodat hulle in staat sal wees om die dwalinge wat aan hulle verkondig word, te beoordeel en daarom dan nie hulle standvastigheid verloor nie (Breed, 1994:343-344). Dit blyk dus dat iemand wat nie

4 Breed (1994:338-339) toon aan dat Petrus met $\gamma \nu \omega \dot{\sigma} \sigma \in \mathrm{L}$ in 3:18 na begripsvermoë

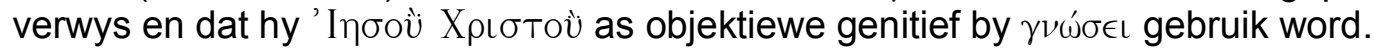


begripsvermoë by sy geloof voeg nie, die gevaar loop om sy innerlike standvastigheid te verloor.

Petrus wys in 2:12 op 'n eienskap van die valse leraars wat duidelik verband hou met sy oproep tot die lesers om begripsvermoë by hulle

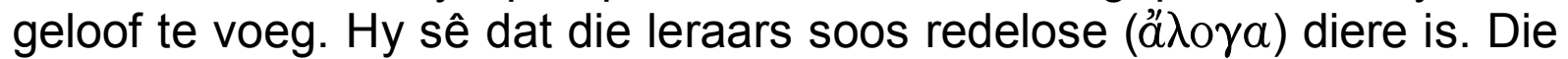
woord ă $\lambda \circ \gamma \alpha$ in 2:12 hou verband met die beheer van inligting oor die algemeen en die klem val spesifiek op die onvermoë om te redeneer (Breed, 1994:253). Terwyl Petrus dus enersyds die lesers oproep om begripsvermoë by hulle geloof te voeg, maak hy andersyds duidelik dat die valse leraars nie oor begripsvermoë beskik nie - hulle het 'n onvermoë om inligting te beheer en kan nie redeneer nie. Petrus bring in 2:12 die onvermoë van die valse leraars om te redeneer met God se oordeel in verband. Hy sê dat hierdie leraars nie slegs in hulle onvermoë om te redeneer met diere ooreenstem nie - soos diere word hulle ook gebore om gevang (o̊ $\lambda \omega \sigma \iota \nu)$ en vernietig te word ( $\phi \theta 0 \rho a ̀ \nu)$. Dit is duidelik dat Petrus die valse leraars sonder begripsvermoë en wat in God se oordeel verkeer, as waarskuwing aan die lesers voorhou. Wie nie oor begripsvermoë beskik nie, loop gevaar om deur die valse leraars meegesleep te word en saam met hulle in God se oordeel te kom 5 .

Uit bostaande blyk dit hoe belangrik dit is dat gelowiges begripsvermoë by hulle geloof voeg. Wie sonder begripsvermoë is, is nie in staat om valse leringe te beoordeel nie en verloor sy innerlike standvastigheid.

\subsubsection{Die verband tussen die deugdelys en die historiese gedeelte van die opsomming van die apostel se leer}

Die frase kaì aúto тоиิTo waarmee vers 5 begin, maak dit duidelik dat die deugdelys in 1:5-7 baie nou aansluit by dit wat voorafgaande gestel word (Kahmann, 1983:33). Bauckham (1983:184) aanvaar dat die skrywer met hierdie frase na die hele 1:3-4 verwys. Die feit dat Petrus egter eers in 1:4b oor die lesers begin handel (Breed, 2000:?), en hy in 1:5-7 die lesers aanspoor, toon dat Petrus met die frase кal aúто тоиิто

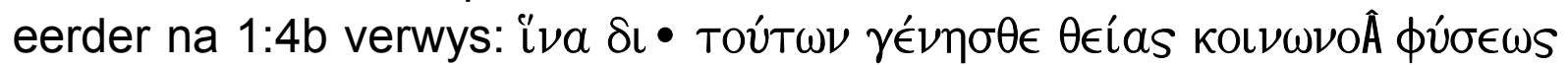

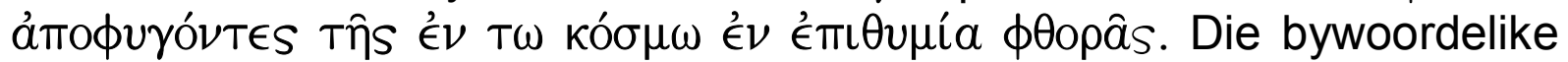

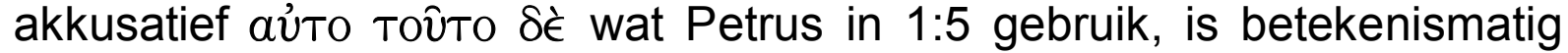
gelyk aan $\delta ı$ ! aủTò (Greijdanus, 1929:248) en kan vertaal word met "en juis daarom".

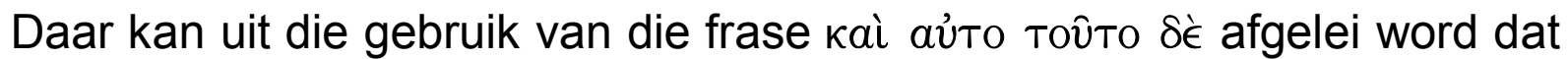
Petrus die verbondsverhouding waarin die lesers tot God te staan gekom het (vgl. Breed, 2000), as die begronding laat dien vir die aanmoediging

Vergelyk ook Petrus se waarskuwing in 2:20. 
wat hy in 1:5-7 tot die lesers rig. Juis omdat die lesers in 'n verbondsverhouding met God staan, rus die verantwoordelikheid op hulle om te doen wat in 1:5-7 van hulle verlang word.

Dit is belangrik om daarop te let dat die deugdelys in 1:5-7 deur die frase

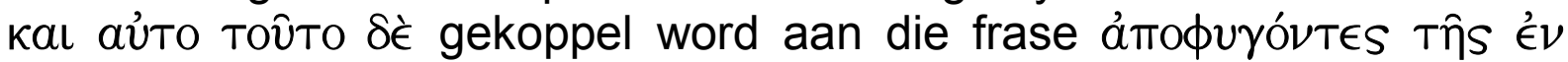

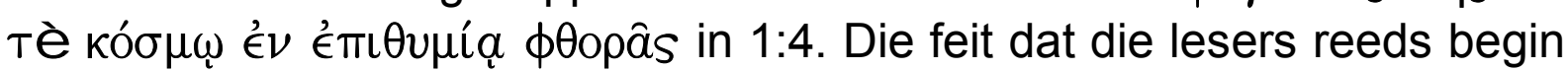
het om die morele verderf te ontvlug (vgl. Breed, 2000), dien ook as begronding vir die aanmoediging om die deugde in 1:5-7 by te voeg. Die lesers moet dus nie ophou om die morele verdorwenheid te ontvlug nie, maar moet daarop voortbou deur by hulle geloof die deugde toe te voeg (Von Speyr, 1961:419).

\section{Die betekenis van die kenmotief in gedagte-eenheid A vir die huidige Suid-Afrikaanse konteks}

- Dit was uit die bestudering van die kenmotief in 2 Petrus 1:3-4 duidelik dat dit vir 'n land soos Suid-Afrika met sy ontstellende morele

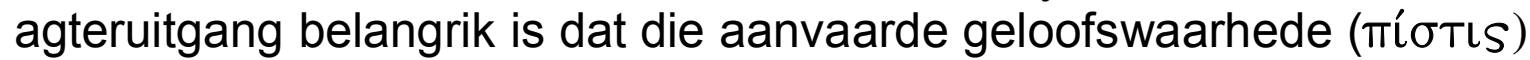
ywerig aan die inwoners van die land verkondig word (vgl. Breed, 2000). Die bestudering van die kenmotief in 2 Petrus 1:5-7 bied belangrike verdere insigte in hierdie verband. Dit blyk uit die verse dat 'n mens wat hierdie geloofswaarhede ontvang het, nie met die besit van hierdie waarhede mag volstaan nie. Die gelowige moet besef dat hierdie geloofswaarhede slegs ' $n$ gronddeug is wat aan hom geskenk is en dat hierdie gronddeug as 't ware roep om die byvoeging van ander deugde. By die gronddeug moet die gelowige 'n lewe volgens God se wil byvoeg (vgl. punt 2.2.2.2). In Suid-Afrika waar "individuals seek an inclusive moral justification for engaging in criminal activity" (Mbeki, 1998) en waar andere sónder om enige regverdiging te bied, byvoorbeeld sedeloos lewe, deelneem aan korrupsie en diefstal, behoort gelowiges se optrede 'n totale kontras daarmee te vorm. Die gelowige wat deur 'n persoonlike verhouding met Jesus Christus die geloofswaarhede as gronddeug ontvang het, moet met ywer 'n lewe volgens God se wil by sy geloof voeg.

- Dit was nodig dat Petrus se lesers begripsvermoë $\gamma \nu \omega \hat{\omega} \iota s$ by hulle geloof voeg sodat hulle die valse leringe wat aan hulle verkondig is, kon evalueer en tot 'n gevolgtrekking kon kom wat ooreenstem met die leer wat die apostels aan hulle verkondig het (vgl. punt 2.2.2.3). In punt 1.1 is aangedui dat daar tans in Suid-Afrika dikwels op moreeletiese terrein teenoorgestelde standpunte met 'n beroep op die Skrif gestel word. Met begripsvermoë moet die gelowige kan oordeel oor standpunte wat tans ingeneem word oor sake soos homoseksualiteit, 
saamwoon, poligamie, genadedood, kloning en aborsie en moet hy kan besluit hoe hy sy lewe volgens God se wil moet inrig. Ook waar kerke in meerdere vergaderings saamkom, byvoorbeeld in sinodes, is dit belangrik dat besluite wat geneem word daarvan getuig dat die vergadering oor begripsvermoë beskik het - dat die gelowiges gesamentlik in staat was om inligting te evalueer en tot 'n besluit te kom wat ooreenstem met dit wat die Skrif aangaande die saak leer.

Daar rus dus op kerke 'n groot verantwoordelikheid om lidmate te begelei om begripsvermoë by hulle geloof te voeg. Dit is belangrik om te besef dat die mens sonder begripsvermoë sy innerlike standvastigheid kan verloor en kwesbaar is vir valse leringe en ook gevaar loop om onder God se oordeel te kom (vgl. punt 2.2.2.4).

- Soos met Petrus se eerste lesers (vgl. punt 2.2.2.3), sal gelowiges wat pas met ' $n$ heidense leefwyse gebreek het, vandag ook baie kwesbaar wees vir 'n valse leer waarin groter toegeeflikheid teenoor 'n sondige leefwyse verkondig word. Indien die jong gelowige deur 'n verdraaiing van die Skrif oortuig kan word dat dit nie onbybels is om mee te doen aan sondige praktyke nie, sou hy maklik tot sy ou leefwyse kan terugkeer. Die verkondiging van "vryheid" (vgl. punt 2.2.2.3) om volgens eie begeertes te lewe terwyl die jong gelowige met groot opoffering worstel om sy lewe nougeset volgens God se wil in te rig, klink vandag nog net so aantreklik soos in die tyd van Petrus se eerste lesers. Kerke behoort daarom voortdurend indringende aandag te gee aan die begripsvermoë van dié mense in hulle midde wat pas tot geloof gekom het sodat hulle nie terugsak in hulle ou leefwyse nie.

- Uit 2 Petrus 1:5-7 blyk dat wanneer die gelowige sy geloof met begripsvermoë verryk, dit alles te doen het met sy verhouding met God. Juis omdat die gelowige in 'n verbondsverhouding met God staan, rus daar op hom 'n verantwoordelikheid om sy geloof met begripsvermoë (en met ander deugde) te verryk (vgl. punt 2.2.2.4). Wie in ' $n$ verbondsverhouding met God staan, het begin om die morele verderf in hierdie wêreld te ontvlug (vgl. Breed, 2000:?) en moet voortbou op hierdie ontvlugting deur begripsvermoë (en ander deugde) by sy geloof te voeg (vgl. punt 2.2.2.4).

\section{Bibliografie}

BAUCKHAM, R.J. 1983. Jude, 2 Peter. Texas : Waco. (Word Biblical Commentary, vol. 50.)

BOLKESTEIN, M.H. 1977. De brieven van Petrus en Judas. Nijkerk : Callenbach.

BREED, D.G. 1994. Die kenmotief in 2 Petrus: 'n eksegetiese studie. Potchefstroom :

PU vir CHO. (Th.D.-proefskrif.) 
BREED, D.G. 2000. Verandering van die moreel-etiese situasie in Suid-Afrika, in die lig van die kenmotief in 2 Petrus 1:3-4. In die Skriflig, 34(2):207-229.

BREED, G. 1999. Landman moet eerlik raak. Beeld: 6, Januarie 15.

DE BRUYN, P.J. 1993. Die Tien Gebooie. Midrand : Varia Uitgewers.

DE KLERK, W. 1998. Die vreemde God en sy mense. Kaapstad : Human en Rousseau.

DU TOIT, A. 1999. Dit gons oor gays. Paulus sou dalk verbaas wees. Beeld: 6, Sept. 27.

DUPONT, J. 1949. Gnosis. La connaissance religieuse dans les êpitres de saint Paul. Louvain : Nauwelaerts.

EASTON, B.S. 1932. New Testament ethical lists. Journal of Biblical Literature, 51:112.

FISHEL, H.A. 1973. The uses of sorites (climax, gradatio) in the Tannaitic period. (In Blank, S.H. \& Weisberg, D.B., eds. Hebrew Union College annual. New York: Dworkin. p. 119-151.)

FORNBERG, T. 1977. An early church in a pluralistic society: a study of 2 Peter. Lund : Carl Bloms Boktryckeri.

GREEN, E.M.B. 1961. 2 Peter reconsidered. London: The Tyndale Press.

GREIJDANUS, S. 1929. De brieven van de apostelen Petrus en Johannes, en de brief van Judas. Amsterdam : Van Bottenburg. (Kommentaar op het Nieuwe Testament.)

GRUNDMANN, W. 1974. Der Brief des Judas und der zweite Brief des Petrus. Berlin : Evangelische Verlagsanstalt. (Theologischer Handkommentar zum Neuen Testament.)

HIEBERT, D.E. 1984. The necessary growth in the Christian life: an exposition of 2 Peter 1:5-11. Bibliotheca Sacra, 141(561):43-54, Jan.-Mar.

IGNATIUS. 1977. The epistle of Ignatius. (In Goold, G.P., ed. Apostolic Fathers Vol. 1. Loeb Classical Library. Cambridge: Harvard University Press. p. 165-278.)

JACKSON, N. 1999. Wêreldwyd voer kerke warm debatte oor homoseksuele sake. Beeld: 11, Augustus 24.

KAHMANN, J.J.A. 1983. De tweede brief van Petrus. Vertaald en toegelicht door prof. dr. J.J.A. Kahmann. (In Kahmann, J.J.A. \& Dehandschutter, B. De tweede brief van Petrus. Vertaald en toegelicht door prof. dr. J.J.A. Kahmann. De brief van Judas. Vertaald en toegelicht door dr. B. Dehandschutter. Boxtel : Katholieke Bijbelstichting. p. 11-112.)

LANDMAN, C. 1999. Poligamie, ditsim. Tyddeel is ons voorland, dames. Beeld: 10, Januarie 14.

LOUW, J.P. \& NIDA, E.A. 1988a. Greek-English lexicon of the New Testament based on semantic domains. (Vol. 1.) New York : United Bible Societies.

LOUW, J.P. \& NIDA, E.A. 1988b. Greek-English lexicon of the New Testament based on semantic domains. (Vol. 2.) New York : United Bible Societies.

MBEKI, T. 1998. Toespraak gelewer tydens 'n spitsberaad op 10 November. Kaapstad. (Ongepubliseer.)

SCHLATTER, D.U. 1964. Die Briefe des Petrus, Judas, Jakobus, der Brief an die Hebräer. Stuttgart : Kalwer Verlag.

VAN HOUWELINGEN, P.H.R. 1993. 2 Petrus en Judas: testament in tweevoud. Kampen : Kok. (Commentaar op het Nieuwe Testament.)

VAN ROOY, J.A. 1998. Ons dien nie 'n vreemde God nie! Die Kerkblad, 101(3045):67.

VON SPEYR, A. 1961. Die Katholischen Briefe. 1. Der Jakobusbrief. Die Petrusbriefe. Einsiedeln : Johannes Verlag. 
WIBBING, S. 1959. Die Tugend- und Lasterkataloge im Neuen Testament. Berlin : Töpelmann. (Beihefte zur Zeitschrift für die Neutestamentliche Wissenschaft no. 25.)

\section{Kernbegrippe:}

2 Petrus

begripsvermoë

deugde

geloof

kennis

moreel-etiese verwarring

Key concepts:

2 Peter

faculty of comprehension

faith

knowledge

moral ethical confusion

virtues 